\title{
Five-year plan in four: kolkhoz propaganda in film and documentaries in Estonia
}

\author{
Martti Veldi ${ }^{1,1}$, Simon Bell ${ }^{1}$ and Friedrich Kuhlmann ${ }^{1}$ \\ ${ }^{1}$ Estonian University of Life Sciences, Chair of Landscape Architecture, Tartu, Estonia
}

\begin{abstract}
In 1951 the first colour film in was produced Soviet EstoniaValgus Koordis ("Light in Koordi village"). This never-before-seen medium applied effective ideological symbols to visualise the power of collective effort with the scope of difficulties building up the new life in a freshly established collective farm (kolkhoz). It was straightforward propaganda to demonstrate that in spite of difficulties, collective farming was the only correct way to achieve prosperity in the countryside. The theme of the film was to show the goodness of Stalinist improvements in a poor post-war rural community at the end of the 1940s. In a very simple manner, topics such as nationalism, the class struggle, socialist ideology, kulaks, collective ownership, mechanisation of agriculture and large-scale land improvements were presented. To capture the wider audience and to increase social impact, the film also starred the rising opera star Georg Ots, still considered as one of the greatest Estonian opera singers ever. In addition to ideologically charged films, a type of propagandist short documentary, the ringvaade (newsreel) was produced in Soviet Estonia. These concentrated on various aspects of Soviet lifestyle, aiming to demonstrate the achievements of collective ideology, and the high morale of the Soviet working class. We studied these and other examples in order to examine the range of themes and motifs presented in them, focusing on the ideological impact on the rural landscape caused by mechanisation, forest management and land melioration. What is revealed is an attempt to persuade the new kolkhozniki (collective farmers) of the benefits of the new system - which, ironically, had dispossessed many of them of their own farms which they had built up in the inter-war years (and which were restored to them after the collapse of the Soviet system in the 1990s).
\end{abstract}

\section{Introduction}

In 1944, as the Red Army advanced out from Leningrad into and across the Baltic States there were fierce battles between it and the retreating Germans (Estonians fought on both sides). After putting up a stiff resistance the Germans were expelled, and the victorious Red Army established control over what became the Estonian Soviet Socialist Republic. Immediately, in the face of devastation, deaths, refugees and a continuing threat from partisans, the new socialist society was promoted and constructed by the

\footnotetext{
${ }^{1}$ Corresponding author: martti.veldi@emu.ee
} 
newly installed administrators, party officials and state security organs (NKVD). The period from 1944 to 1949 saw the establishment phase of the new state and the application of all the means at its disposal to establish its power by both coercion and persuasion. The Soviet Union had already collectivised agriculture in places like the Ukraine - with appalling consequences [1] and sought to do so in the Baltic States.

The same conditions featured in Estonia as in Ukraine, such as the portrayal of the better-off farmers as kulaks and class enemies and the poor peasants as the morally superior class. As part of the armoury brought to bear on the collectivisation process propaganda played a major role. Firstly, it aimed at building up the new state and justifying the activities; later it was about celebrating the real or fictitious achievements of industry and agriculture. One particular aspect which was always popular was the idea of heroic achievements by individual workers - such as the so-called heroic works or stakhanovites [2] - or achieving the all-important five-year plans early, perhaps in four years instead of five.

In his classical study on the power of propaganda, Munitions of the Mind, Philip Taylor defines propaganda as "the communication of ideas designed to persuade people to think and behave in a desired way. Propaganda is about persuading people to do things which benefit those doing the persuading, either directly or indirectly" [3: 6].

Systematic propaganda practised by the Soviet Union can be understood as a tool for consolidating and maintaining the Communist Party in power [4].

Because Lenin had postulated that of all the arts the most important for us is the cinema, cinematography enjoyed a strong position in the Soviet Union, and was well financed both during and after the war [5]. The industry became very effective and skilled in producing films which, whether for entertainment or for information, always contained significant propaganda content as well as adhering to the tenets of Socialist Realism. Films of both types were produced almost immediately once Estonia was incorporated into the Soviet Union.

The first colour film ever made in Soviet Estonia, Valgus Koordis ("Light in Koordi village"), was produced already in 1951 [6], which was quite early for a colour film even in the wider European context. This never-before-seen medium applied effective ideological symbols in order to visualise the power of collective effort within the scope of the difficulties encountered in building up the new way of life in a freshly established collective farm (kolkhoz). The film was directed by an Austrian film maker, Herbert Rappaport, who had emigrated to the Soviet Union straight from Hollywood in 1936 and was well-known for his expertise.

Already, towards the end of the Second World War in 1944, the propagandist short documentaries or newsreels known by the title Nõukogude Eesti ringvaade (literally: a look around Soviet Estonia) were produced by the Leningrad Studio of Cinema Chronicles. In 1945 the equivalent Tallinn Studio of Cinema Chronicles, specialising in newsreels, started up. The newsreels focused on various aspects of Soviet lifestyle, aiming to demonstrate the achievements of collective ideology, and the high morale of the Soviet working class.

In this paper, we examine a sample of early Soviet Estonian films in order to identify how the collectivisation of agriculture was portrayed - in part it was about mobilising the masses for the work, in part it was about the inevitability and correctness of collectivisation and in part it was the struggle against nature, especially wetlands or swamps which had to be conquered (drained) through heroic efforts in order to provide more production. We watched the sample of films in order to identify the propagandist content, as expressed through the plotting, through the characterisation and through 
the dialogue, focusing on the expression of the ideological impact on the rural landscape caused by mechanisation, forest management and land melioration.

\section{“Light in Koordi village"}

The film is based on a story by Hans Leberecht, originally published in 1949 in the Russian periodical Zvezda (Star). Ironically, only six months after the mass deportation of so-called kulaks to Siberia, carried out in March 1949, Leberecht's novel received the Stalin Prize for fiction, cited as an outstanding example of synthesis of Soviet ideology and socialist realism. The book was translated into 23 languages and became the calling-card of Estonian literature for at least for a decade [7].

The plot of the film takes place in a small post-war Estonian village named Koordi, when the main character, Paul Runge (who is portrayed by the famous opera singer Georg Ots), returns from the war (fighting in the Red Army) back to his home village located in the middle of a swampy territory. It is set at the time when the Soviet policy was implemented to divide old farms between new landowners. Runge finds the local rural community torn between the old and (relatively) wealthy landlords (kulaks), and poor farmers (also referred to as paupers), who have recently become landowners and who are struggling just to survive.

As well as the class war between the kulaks and poor farmers, the fight against swamps and wetlands becomes one of the main themes in the film. Already, when Runge arrives from the war by train, the station at which he gets off is named "Sooküla", literally "Swamp village". Runge is so eager to demonstrate his thirst for improvement, that the first thing he does on his way home from the station is to help an old unknown farmer to plough his field, while still in uniform wearing his medals and taking up heroic poses (Fig. 1.).
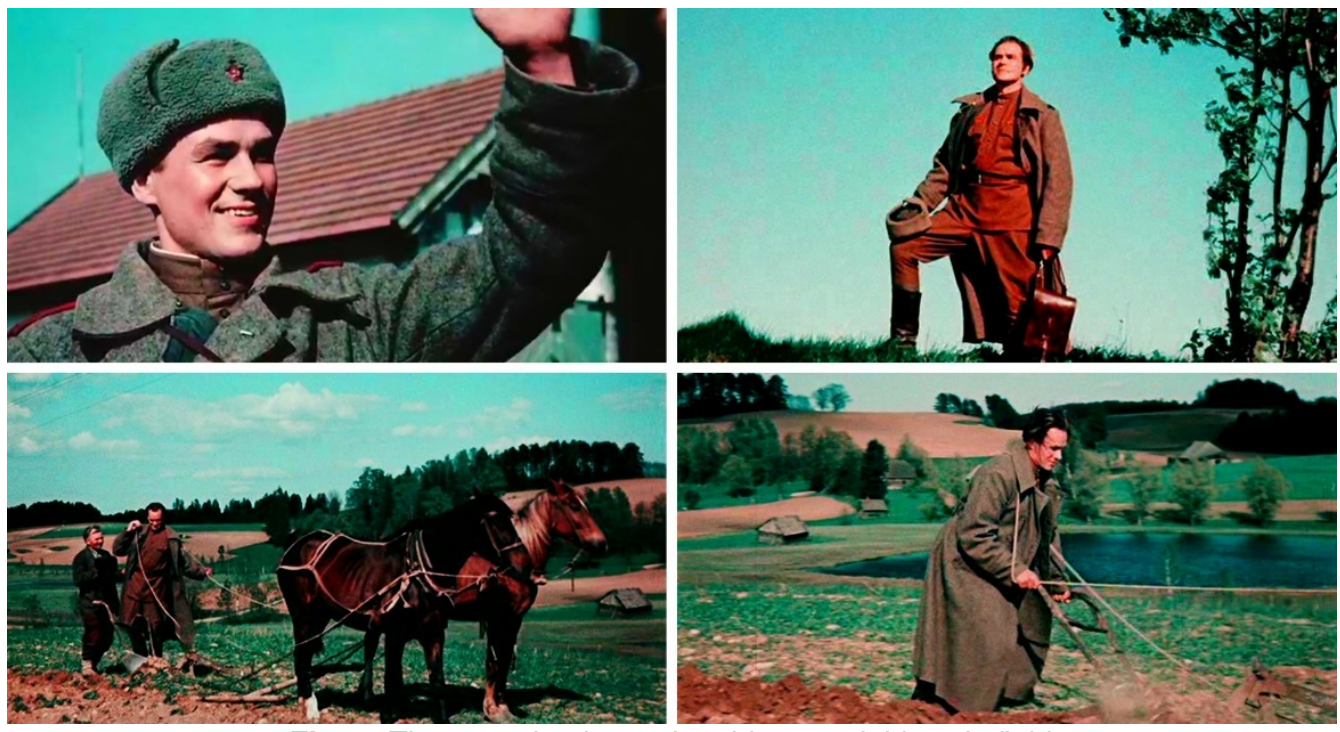

Fig. 1. The returning hero ploughing a neighbour's field

(Still frames reproduced with the permission of the Estonian Film Archive)

Right from the start Runge is depicted as the war hero who has returned home in order to lead his people on the right track, which in this case is collectivisation of the local farms. During the first half of the film the protagonist is always dressed in his Red 
Army uniform, wearing his medals, even when he is working in the fields - so as to reinforce his heroic status and to transfer this to the heroism of transforming the land.

When Runge and his friends have their first evening meal together he raises to toast the Soviet rule:

Let's drink to the Soviet rule, which gave us land and opened up the road to a new life! Cheers! Cheers! Cheers!

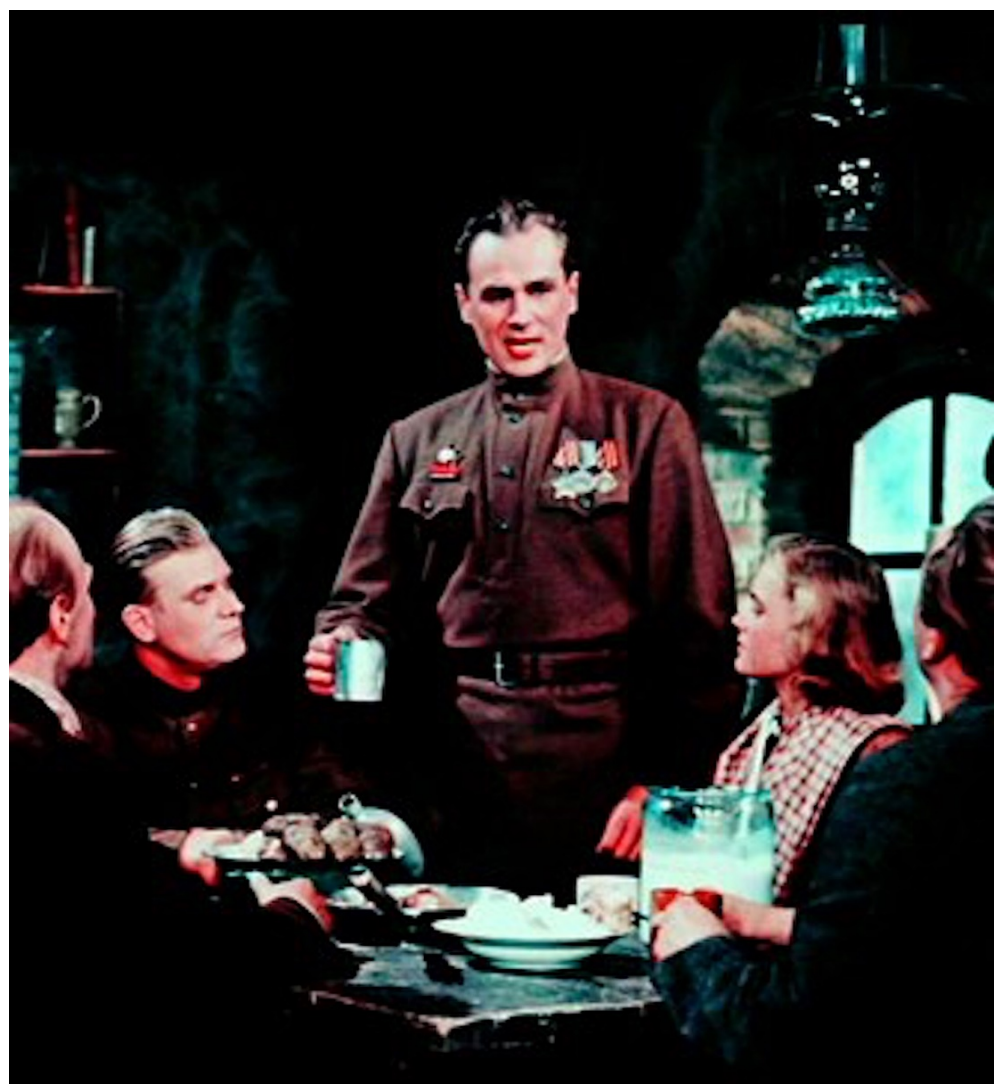

Fig. 2. The hero of the film, Paul Runge, raising a toast

(Still frame reproduced with the permission of the Estonian Film Archive)

On his return home, the war hero expects to receive a prosperous farm from the state but instead he receives a poor and shabby place, which needs lots of work. On their arrival to their new home, Runge and his wife (a daughter of a kulak, who married against her fathers will: another rather obvious reference to the conflicts between the two classes) have the following conversation:

Runge (with dreamy voice): One of my friends told me, that the similar country folk like us have proper plumbing with running water like in town, and all the work is done with electricity. In the evenings, they go to the club, to listen to the music.

Runge's wife: Where is it like that, Paul?

Runge: In Russia...

At the end of the film, when Runge visits his friend in Russia to study the benefits of collective farming, and witnesses that everything he was told, was true. In actual fact, the dream Runge had eventually came true and reached the furthest corners of the 
countryside some 30 odd years later, in the 1980s, when the extensive modernisation of the rural areas of Estonia had finally started.

The film is highly charged with Stalinist ideology and all the important conversations take place under Stalin's picture. For example, when a local official explains to his comrades the need for melioration:

For hundreds of years, people have dreamt about draining the swamps...but until now nothing came of it, and could be possible. In order to succeed one precondition is needed: collective ownership! Without collectivisation, there is no point in thinking about draining the wetlands. And this again proves today conversation of today. Collectivisation has become vital! We have to help the people to step on the road of collective ownership. I wish you luck, comrades!

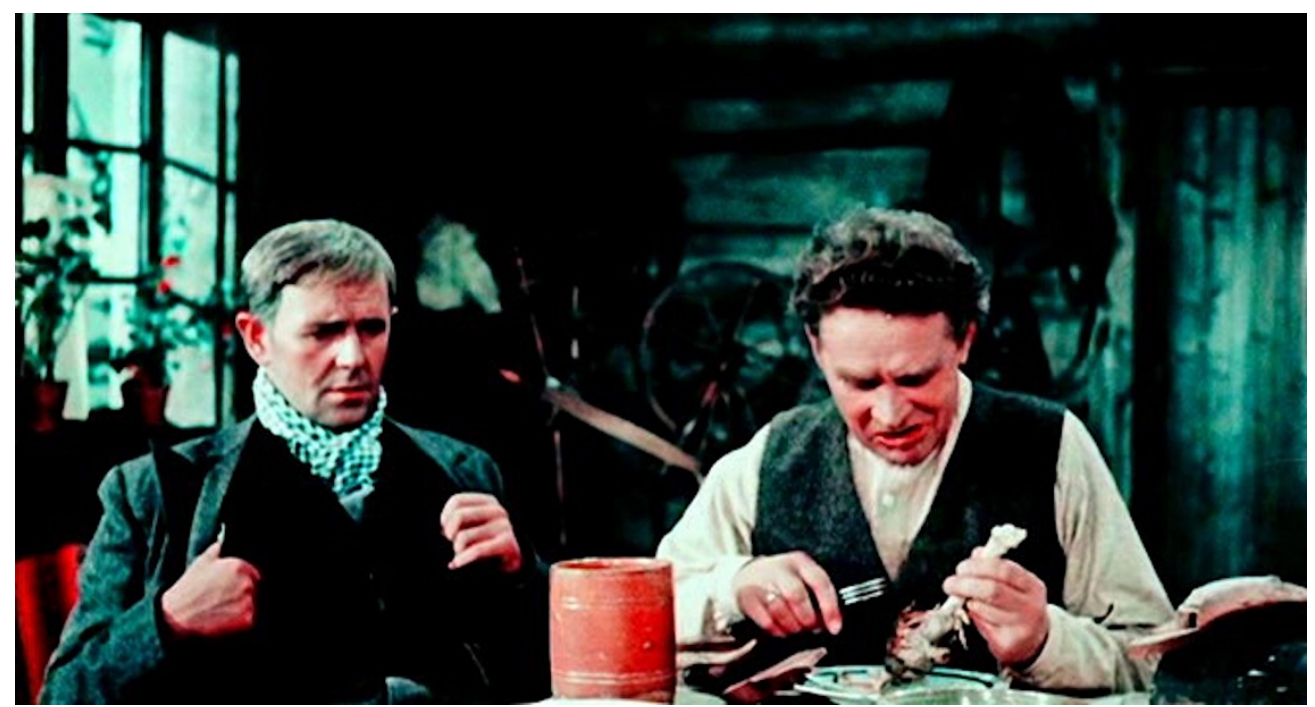

Fig. 3. Kulaks, the better-off farmers, are depicted as enemies of the peasants and workers (Still frame reproduced with the permission of the Estonian Film Archive)

Throughout the movie, old landowners are depicted as vicious enemies of the working people, who poison rural society, which is seeking equality between the classes. The kulaks are shown with patronising grins, eating meat, justifying their land ownership and, through treachery, forcing other people to work for them (Fig. 3.). The kulaks with the help of the forest brothers (anti-communists, who were hiding in forests) try to sabotage the work of the new landowners, especially those who favour collectivisation. They send threats through the post depicting the skull and crossbones with the message: If you want to live, leave the village! Eventually the forest brothers set Runge's farm on fire. The film actually attempts to justify the mass deportation of better-off landowners, pointing out that for the greater good the "enemy of the people" had to be removed in order to achieve communism.

This is when Runge decides to go to Russia to visit his war friend and study the secrets of collective agriculture. The kolkhoz in Russia is depicted almost paradise-like: huge heaps of grain, lots of machinery, science based agriculture, kindergarten, happy workers surrounded by culture and intellectual conversations (Fig. 4.). 

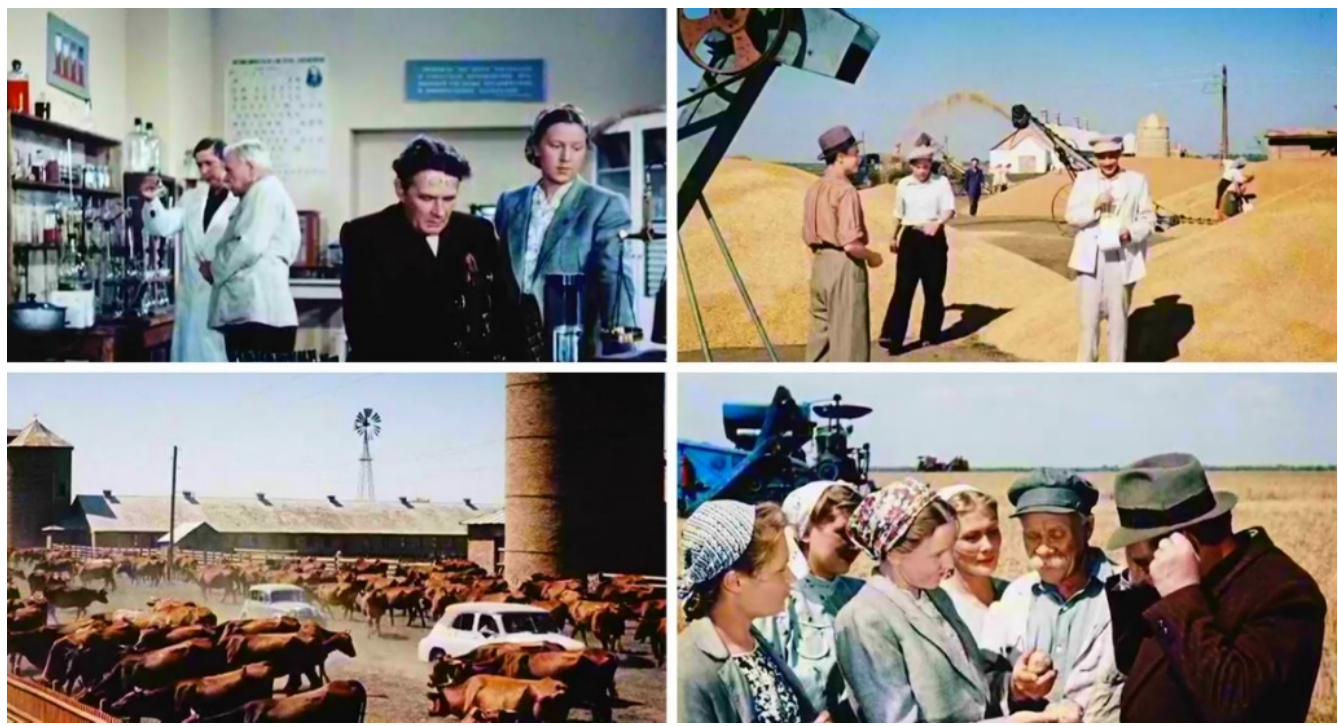

Fig. 4. Images of the visit to a Russian kolkhoz where the almost mythical achievements are presented (Still frames reproduced with the permission of the Estonian Film Archive)

On their return from Russia, Runge and his father in law (a former kulak miraculously transformed into an exemplary kolkhoznik) establish the kolkhoz named "New Life", and with singing and dancing prosperity arrives. Meanwhile, all the wetlands are drained, and unusable swamps are turned into fertile agricultural land (Fig. 5.).
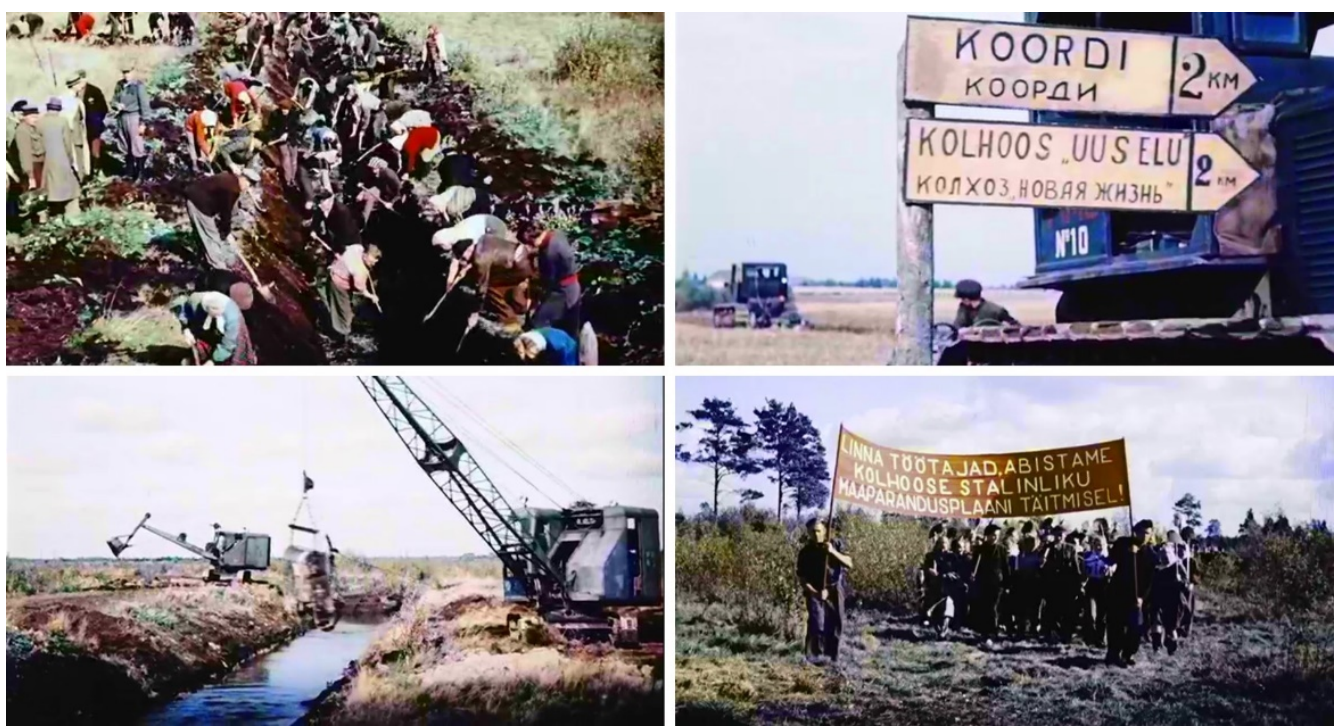

Fig. 5. Combined use of machinery and common effort enable unusable wetlands to be turned into fertile fields. (Still frames reproduced with the permission of the Estonian Film Archive)

In its essence, "Light in Koordi village" follows a very similar plot archetype familiar from Hollywood cowboy movies [7], where the pioneers have to conquer the wild prairie and win their fights with natives. In the wild east, the dry and dusty prairie is replaced by wet swamps that need to be drained and turned into fertile agricultural fields. The kulaks, as enemies of the working people, take the place of savage natives. The film is 
half-musical, half-drama, with an original soundtrack demonstrating how hardship can be overcome with music and dancing.

In 1984 the film was described by the film critic Tatjana Elmanovitš as "A dream film, a utopian dream of country life with rivers overflowing with milk. Collective farms are established together with ploughing, singing, and dancing folk dances. The restructuring of country life is symbolised by the blind Saamu, who regains his sight" [8: 19].

\section{Newsreel "Soviet Estonia”}

The propagandist documentary newsreel "Soviet Estonia" started in 1944 and was produced during the whole Soviet Era. The structure of the "show" was already established by the end of the 1940s: each newsreel lasted for $6-7$ minutes containing $4-6$ topics. In the following decades, the footage segments and the number of topics gradually rose.

As example cases, we looked at the "Soviet Estonia" newsreels produced in 1951, the same year as the movie "Light in Koordi village" was released. From the Estonian Film Archive ${ }^{2}$ we could find altogether 37 newsreel footages produced in 1951. Considering the economically extremely difficult post-war period, the number of films is astonishingly high.

When analysing these newsreels, we managed to extract 11 different recurring themes including: 1) industry 2) kolkhoz life 3) forestry 4) fishing 5) political propaganda 6) military parades 7) culture 8) sports 9) everyday life 10) portrayals of workers and 11) education and science. The 37 newsreels produced in 1951 included 158 different footage segments in total.

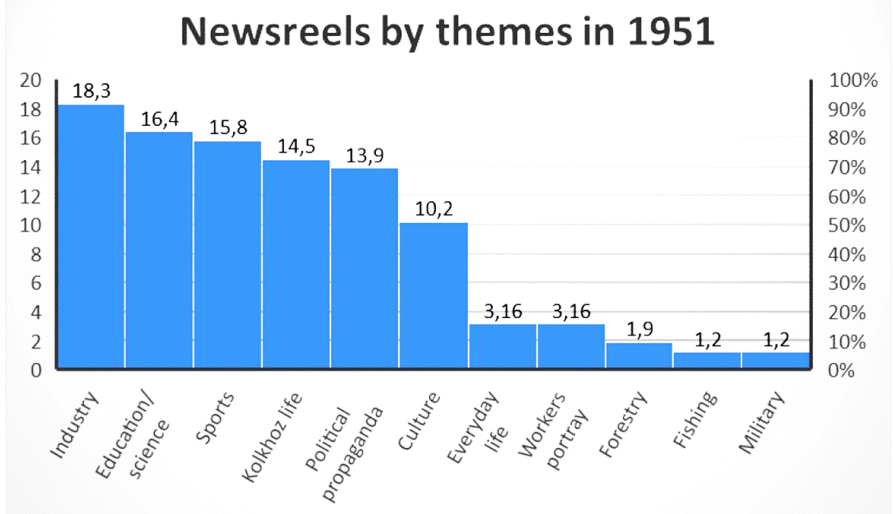

Fig. 6. The most popular themes of newsreels in 1951, derived from an analysis of 37 newsreels made in 1951 (Source: the authors)

It was no surprise that the most common theme to be covered in the newsreels was the development of industry with 29 different clips (Fig. 6.), making up more than $18 \%$ of the produced footages. At the same time, surprisingly, education/science $(16,4 \%)$ and sports $(15,8 \%)$ were promoted slightly more often than specific political propaganda $(13,9 \%)$ or the collective lifestyle $(14,5 \%)$ (although, of course it was all propaganda).

2 See the kroonika [chronicle] genre at the Estonian Film Archive's database (http://www.eha.ee/fa/public/index.php). 


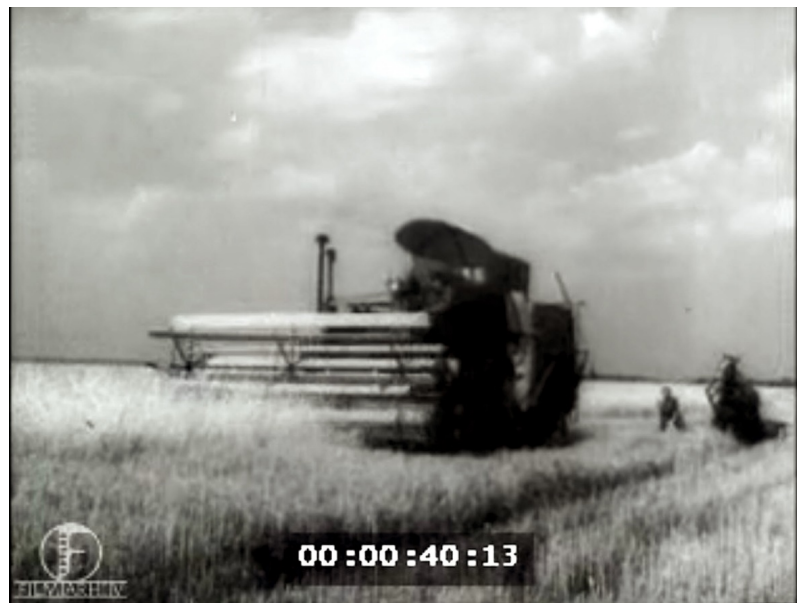

Fig. 7. The advantages of modern technology and machinery compared to traditional ones was a common topic in newsreels.

(Still frames reproduced with the permission of the Estonian Film Archive).

One of the interesting topics of the newsreels was to present special portrayals of working-class heroes, such as mechanics, bus and engine drivers, milkmaids, combiners and tractorists. The other goal was to make ordinary people proud of their country by showing off with excursion-like overviews of collective farms, factories, industrial establishments, and land improvements. Besides promoting collective working-class ideology, the newsreels also covered events of sports and culture, giving an impression of a balanced stable society.

It has been pointed out [9] that the newsreels very seldom depicted reality but were mostly staged following a strict script.

The carrying idea of the newsreel was to demonstrate the achievements of Soviet Estonia in order to assure its people that Soviet rule and the path chosen by the Communist Party is the right one.

\section{Conclusions}

Considering the economically extremely difficult post-war period, the quality and number of films and documentaries produced during that time was very high. Already in the early 1950s top professionals were used in cinema, and a considerable amount of resources was invested into visual propaganda, which became an important ideological tool for influencing the confused and suffering masses.

The film "Light in Koordi village" can be understood as a propagandist utopian "dream film" advocating collectivisation, Stalinist ideology and man's right to use natural resources as extensively as possible. While, in the film, collectivisation was carried out with singing and dancing, the real situation included mass deportations and a state of constant fear and poverty.

The overall idea of introducing new cinematographic methods was to convince the general public of the correctness and benefit of Stalinist improvements, which in the newsreels covered a very wide spectrum of topics ranging from the improvements of collectivisation and industry to education, culture and sport. The carrying idea of the newsreel was to demonstrate the achievements of Soviet Estonia in order to assure its people that the Communist rule and the chosen path was the right one. At the same 
time, the documentaries very seldom depicted reality, but were mostly staged following a strict script, leaving the public completely deceived.

\section{Acknowledgements}

MODSCAPES is a collaborative research project funded under the HERA - Humanities in the European Research Area 3rd Joint Research Programme dedicated to "Uses of the Past" (20162019). This project has received funding from the European Union's Horizon 2020 research and innovation programme under grant agreement $n^{\circ} 649307$.

\section{Short resumes}

Martti Veldi MSc is an archaeologist and a Junior Researcher at the Estonian University of Life Sciences in Tartu, Estonia. He is also an inspector in the Estonian Heritage board responsible for identifying and protecting cultural heritage monuments.

Simon Bell PhD is Chair professor at the Estonian University of Life Sciences and Associate Director of the OPENspace Research Centre at the University of Edinburgh. He has been president of ECLAS, the European Council of Landscape Architecture Schools between 2012 and 2018.

Friedrich Kuhlmann Dipl.Ing is a landscape architect and Chief Specialist at the Estonian University of Life Sciences in Tartu, Estonia. He studied landscape architecture at the Technical University in Berlin and was a studio tutor there as well as running his own office.

\section{References}

1. APPLEBAUM, A. 2018. Red Famine: Stalin's War on the Ukraine, London, Penguin Books.

2. The Stakhanov Movement (1938). Newsreel [The Russian State Documentary Film \& Photo Archive at Krasnogorsk (RGAKFD), Archive $n^{\circ}$ 3915]. RU, Moscow: Московская студия кинохроники [Moskovskaya studiya kinokhroniki, Moscovite Newsreel Studio]. Retrieved from: http://soviethistory.msu.edu/1936-2/year-of-thestakhanovite/year-of-the-stakhanovite-video/the-stakhanov-movement-1938/ [available on 5 September 2018].

3. TAYLOR, P.M. 2003. Munitions of the mind. A history of propaganda from the ancient world to the present day, Manchester University Press. DOI: https://doi.org/10.7765/9781847790927

4. MIIL, M. 2014. Nõukogude propagandasüsteemi toimimine ajakirjanduse argipraktikate kaudu [Functioning of the Soviet propaganda system through everyday journalistic practices], PhD dissertation, Tartu, Tartu Ülikooli Kirjastus Tartu University Press. DOI: https://doi.org/10062/42941

5. KENEZ, P. 2001. Cinema and Soviet Society: From the Revolution to the Death of Stalin, London-New York, I.B. Tauris.

6. Valgus Koordis (1951). [Film] Directed by H. RAPPAPORT. Estonia: Tallinnfilm AS. [held at the Estonian Film Archive, record $n^{\circ}$ 4764: http://www.eha.ee/fa/public/index.php]

7. VEIDEMANN, R. 2010. "Eesti-vene kirjandusliku kommunikatsiooni kurioosum: Hans Leberechti jutustus 'Valgus Koordis' (1948-1949)" [A curiosity of EstonianRussian fictional communication: Hans Leberecht's story "Light in Koordi" (19481949 ) in L. Pild (ed.), Россия и Эстония в XX веке: диалог культур [Rossiya i 
Estoniya v XX veke: dialog kul'tur / Russia and Estonia in the $20^{\text {th }}$ century: a dialogue of cultures], Tartu, Tartu Ülikooli Kirjastus - Tartu University Press: 300308. Retrieved from: https://www.etis.ee/Portal/Publications/Display/9a8bf61581bb-4b49-84c6-02f3a3e9086e [available on 31 January 2019].

8. ELMANOVITŠ, T. 1984. "Eesti mängufilmi žanrijooni I" [Feature-lines of Estonian motionpictures I], Teater. Muusika. Kino, $\mathrm{n}^{\circ}$ 10, 19-32. Retrieved from: http://www.digar.ee/id/nlib-digar:133512 [available on 31 January 2018].

9. TOMINGAS, I. 2004 [18 August]. "Ringvaade - Ajastu peegel valgel laial kinolinal" [Mirror of an era on the wide screen], Postimees. Retrieved from: https://www.postimees.ee/1428899/ringvaade-ajastu-peegel-valgel-laial-kinolinal [available on 31 January 2019]. 